\title{
Correction to: 2021 Scientific Session of the Society of American Gastrointestinal and Endoscopic Surgeons (SAGES), Las Vegas, Nevada, 31 August-3 September 2021 (Volume 35, Supplement 1)
}

Published online: 24 November 2021

(c) Springer Science+Business Media, LLC, part of Springer Nature 2021

Correction to: Surgical Endoscopy

https://doi.org/10.1007/s00464-021-08746-x https://doi.org/10.1007/s00464-021-08747-w https://doi.org/10.1007/s00464-021-08748-9 https://doi.org/10.1007/s00464-021-08749-8 https://doi.org/10.1007/s00464-021-08750-1

This article was updated to include its subtitle as part of the title in the article metadata.

Publisher's Note Springer Nature remains neutral with regard to jurisdictional claims in published maps and institutional affiliations.

The original article can be found online at https://doi.org/10.1007/ s00464-021-08746-x, https://doi.org/10.1007/s00464-021-08747w, https://doi.org/10.1007/s00464-021-08748-9, https://doi.org/10. 1007/s00464-021-08749-8, https://doi.org/10.1007/s00464-021-

08750-1. 